\title{
Correction to: The Protective Effects of Butorphanol on Pulmonary Function of Patients with Obesity Undergoing Laparoscopic Bariatric Surgery: A Double-Blind Randomized Controlled Trial
}

\author{
Xiu-li Wang ${ }^{1} \cdot$ Si Zeng ${ }^{2} \cdot$ Xiao-xiao $\mathrm{Li}^{1} \cdot$ Ye Zhao ${ }^{1} \cdot$ Xing-he Wang $^{1} \cdot$ Tong $\mathrm{Li}^{1} \cdot$ Su Liu ${ }^{1,3}$ \\ Published online: 29 June 2020 \\ (C) Springer Science+Business Media, LLC, part of Springer Nature 2020
}

\section{Correction to: Obesity Surgery https://doi.org/10.1007/s11695-020-04755-2}

In the original article some of the references were ordered incorrectly.

The correct reference 34 is: Hardman JG, Aitkenhead AR. Estimating alveolar dead space from the arterial to end-tidal $\mathrm{CO}(2)$ gradient: a modeling analysis. Anesth Analg. 2003;97(6):1846-51.

From reference 35 forward, all references are increased by one number and appear as below:

35. Chernik DA, Gillings D, Laine H, et al. Validity and reliability of the Observer's Assessment of Alertness/ Sedation Scale: study with intravenous midazolam. J Clin Psychopharmacol. 1990;10(4):244e51.

36. Flier S. How to inform a morbidly obese patient on the specific risk to develop postoperative pulmonary complications using evidence-based methodology. Eur J Anaesthesiology. 2006;23(2):154-9.

The online version of the original article can be found at https://doi.org/ 10.1007/s11695-020-04755-2

\section{Su Liu}

w15996933165@163.com

1 Jiangsu Province Key Laboratory of Anesthesiology, Xuzhou Medical University, Xuzhou, Jiangsu, China

2 Department of Anesthesiology, Sichuan Academy of Medical Science \& Sichuan Provincial People's Hospital, University of Electronic Science and Technology of China, Chengdu, Sichuan, China

3 Department of Anesthesiology, The Affiliated Hospital of Xuzhou Medical University, 99 Huaihai West Road,

Xuzhou 221000, Jiangsu, China
37. Writing Committee for the PROBESE Collaborative Group of the PROtective VEntilation Network (PROVEnet) for the Clinical Trial Network of the European Society of Anaesthesiology. Effect of Intraoperative High Positive EndExpiratory Pressure (PEEP) With Recruitment Maneuvers vs Low PEEP on Postoperative Pulmonary Complications in Obese Patients: A Randomized Clinical Trial. JAMA. 2019;321(23):2292-305.

38. Matthay MA, Bhattacharya S, Gaver D,et al. Ventilatorinduced lung injury: in vivo and in vitro mechanisms. Am J Physiol Lung Cell Mol Physiol. 2002; 283(4):L678-82.

39. Zhang S, Zhou Y, Zhao L, et al. K-opioid receptor activation protects against myocardial ischemia-reperfusion injury via AMPK/Akt/eNOS signaling activation. Eur J Pharmacol. 2018;833:100-8.

40. Zhou Y, Wang Y, Wang X, et al. The Protective Effects of K-Opioid Receptor Stimulation in Hypoxic Pulmonary Hypertension Involve Inhibition of Autophagy Through the AMPK-MTOR Pathway. Cell Physiol Biochem. 2017;44(5):1965-79.

41. Franklin C, Fortepiani L, Nguyen T, et al. Renal responses produced by microinjection of the kappa opioid receptor agonist, U50-488H, into sites within the rat lamina terminalis. Pharmacol Res Perspect. 2015;3(2):e00117.

42. Peng P, Huang LY, Li J, et al. Distribution of kappaopioid receptor in the pulmonary artery and its changes during hypoxia. Anat Rec (Hoboken). 2009;292(7):1062-1067.

43. Shekar K, Fraser J F. Ventilator-induced lung injury. N Engl J Med. 2014;370(4):979.

44. Gao TT, Jiang L. Obesity exacerbates pulmonary vascular endothelial injury caused by mechanical ventilation. Int $\mathrm{J}$ Anesth Resu. 2018;(3):250-3. Chinese

45. Shah RJ, Wickersham N, Lederer DJ, et al. Preoperative plasma club (clara) cell secretory protein levels are associated with primary graft dysfunction after lung transplantation. Am J Transplant. 2014;14(2):446-52. 
46. Ide S, Minami M, Ishihara K, et al. Abolished thermal and mechanical antinociception but retained visceral chemical antinociception induced by butorphanol in mu-opioid receptor knockout mice. Neuro pharmacology. 2008;54(8):1182-8. 47. Black D. The kappa opioid receptor is associated with the perception of visceral pain. Gut. 1998;43(3):312-3.

48. Boom M, Niesters M, Sarton E, et al. Non-analgesic effects of opioids: opioid-induced respiratory depression. Curr Pharm Des. 2012;18(37):5994-6004.
49. Pasternak GW. Mu Opioid Pharmacology: 40 Years to the Promised Land. Adv Pharmacol. 2018;82:261-91.

50. Commiskey S, Fan LW, Ho IK. Butorphanol: effects of a prototypical agonist-antagonist analgesic on kappa-opioid receptors. J Pharmacol Sci. 2005;98(2):109-16.

Publisher's Note Springer Nature remains neutral with regard to jurisdictional claims in published maps and institutional affiliations. 